\title{
Design and Development of Pedal Pump for Low-Lift Irrigation
}

\author{
M. SERAZUl ISLAM ${ }^{1 *}$, M. ZAKARIA HosSAIN ${ }^{2}$ AND M. ABUl KHAIR ${ }^{3}$ \\ ${ }^{1}$ School of Agriculture and Rural Development, Bangladesh Open University, Gazipur, Bangladesh \\ ${ }^{2}$ Division of Environmental Science and Technology, Graduate School of Bioresources, Mie University, Japan \\ ${ }^{3}$ Department of Irrigation and Water Management, Bangladesh Agricultural University, Mymensingh Bangladesh
}

\begin{abstract}
A study was undertaken to design and construct a low-lift pedal pump for use in small irrigation project areas. For this purpose, different types of piston valves and check valves were constructed and tested at different suction heads in the laboratory to evaluate their performances. After several trials, Piston valve type-II and check valve type-III were found to be suitable. The average discharges of the pumps ranged from 93.27 to 53.27 litre per second were noted against heads of 0.60 to $2.0 \mathrm{~m}$ respectively, when piston valve type-II and check valve type-III were used. During pedal pump operation, less input power was needed and it can be operated by one adult man for a long time (more than 2 hours) continuously without being tired. Efficiency of the pump was 46.53 percent against a head of $1.65 \mathrm{~m}$. The pedal pump can be constructed using local materials and skill. It would be suitable to irrigate small and fragmented land holdings, especially to pump water from a shallow depth (up to $2 \mathrm{~m}$ ) to irrigate small plots like vegetables and seed beds with less physical effort.
\end{abstract}

Key words: Pedal pump, discharge rate, power requirement, efficiency, piston valve and check valve.

\section{INTRODUCTION}

Irrigation plays a vital role as a leading input because the productivity of other inputs such as improved seed and fertilizers largely depend on the availability of ensured water supply in the fields. With the supply of irrigation water, most of the agricultural lands can be brought under cultivation of high yielding crops. The productivity of the land now producing food under natural condition can be increased considerably by the application of supplemental irrigation. The socioeconomic condition of Bangladesh farmer does not permit large scale irrigation investment. Hence, introduction of small scale irrigation like pedal pumps can play a vital role for increasing food grain production in Bangladesh. Capital intensive technology like deep tubewells, shallow tubewells are beyond the purchasing capacity of the poor farmers, while they can afford labour intensive technologies such as pedal pump, hand pumps, rower pumps, treadle pumps etc. due to their lower cost. In the context of Bangladesh, where labours are abundant and most of the farmers are poor, the pedal pump seems to be an appropriate irrigation technology. Such kind of irrigation technologies are operated and maintained by farmers themselves from their own capital for producing crop in the small fragmented lands. The average small farm sizes spreading over a number of scattered plots are unsuitable to irrigate with a large size of stream. But, the manually

* Corresponding author: Lecturer (Agril. Engg.); SARD; BOU, Gazipur-1705, Bangladesh; E-mail: serazsard4@yahoo.com

(C) 2006 School of Agriculture and Rural Development, Bangladesh Open University, All rights reserved. 
operated technology with a small stream size is suitable for small and fragmented farm holding and involves less mechanical and maintenance problems. In fact the poor farmers represent $70 \%$ of population in Bangladesh and they own only $20 \%$ of total land (GOB, 1986). Due to their extreme poverty, they are gradually joining the landless group. In this context, manually operated pedal pump is helpful for poor farmers to reduce poverty. The current success of manually operated pump can be explained in terms of factors like appropriate design, low cost, effective marketing, and high cash returns (Orr et al., 1991). Some researchers had focused their endeavor on the development of low lift labor-intensive devices and had succeeded to develop some devices of such characters like treadle pump, rower pump, wheel pump, diaphragm pump, blower pump, etc. But these pumps still are not popular in the country due to their low efficiencies and discharges, short service lives, high friction losses and many other mechanical troubles. Operation of the devices is very laborious and operators often complain about their suffering from various health hazards. Nobody can work at much over $1 / 5^{\text {th }}$ of a hp for very long (Allison, 1975). According to survey report (Faruk and Pramanik, 1995) many users of these devices complained about their health troubles and desired to get a better technology requiring less manual power and mechanical troubles. High initial maintenance cost, non-availability of spare parts, requirements of large irrigable land and similar other restrictions make the poor illiterate farmers reluctant to use of deep tubewells and shallow tubewells. But the components of pedal pumps can be locally produced with low-cost and all spare parts are available in the country. Hence, a study is needed to design and develop the pedal pump to make it simple to ensure automatic participation of farmers.

\section{MATERIALS AND METHODS}

\section{Materials required}

PVC pipe (5 inch diameter for cylinder and 2 inch diameter for suction pipe), plastic and cast iron discs for both piston and check valves, rubber bucket, rubber flaps, wooden block $(89 \times 30 \times 10 \mathrm{~cm})$ for pump base, MS rod (for handle and foot board), angle bar, flat bar, nuts and bolts and elbow were collected and the intended pump was constructed in a workshop according to the design.

\section{Description of the pump}

\section{Pump Base}

Wooden block of size $89 \times 30 \times 10 \mathrm{~cm}$ was used as the base to support the pump during operation.

\section{Fulcrum stand}

Fulcrum stand was made from angle bar having the height of $85 \mathrm{~cm}$ which inserted to the wooden base for holding pump handle.

\section{Pump cylinder}

Pump cylinder (12.7 cm diameter) was made from PVC pipe and was fixed with the wooden base. Rubber flap mounted plastic discs (collected from PVC industry) and perforated cast iron discs (made at motor workshop) valves used both as check and piston valve. Pump discharges were allowed to flow through the outlet.

\section{Valves}

The piston (Plunger) and check valves were made at PVC pipe industry and motor workshop with plastic discs and perforated cast iron discs. Rubber bucket placed in between plastic discs/perforated piston plate and follower piston plate to minimize the frictional losses between the valves and cylinder wall. The plunger valve was then attached with pump handle by means of a connecting rod. Different types of piston and check valves, as presented below and shown in Figure 1 to 10, were used to find the optimum types of valve for maximum discharge and reduce friction losses. 


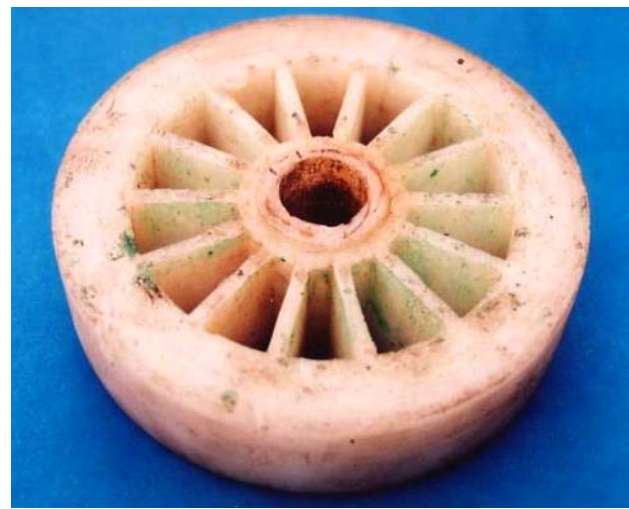

Fig. 1. Piston plate made with plastic disc for piston valve type-I

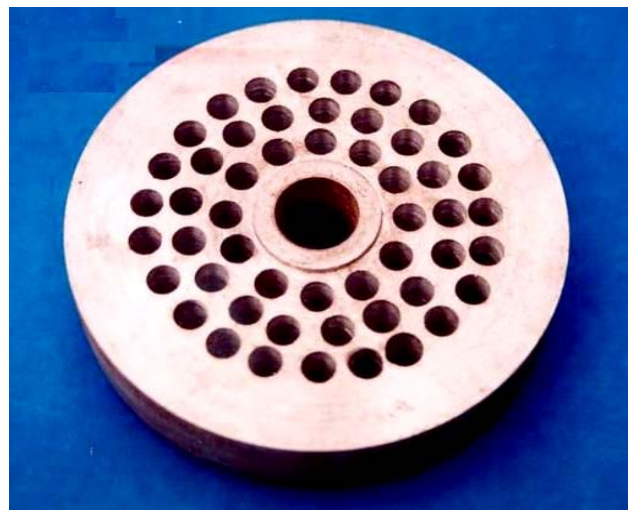

Fig. 3. Piston plate made with perforated cast iron disc of slots size $8 \mathrm{~mm}$ for piston valve type-III

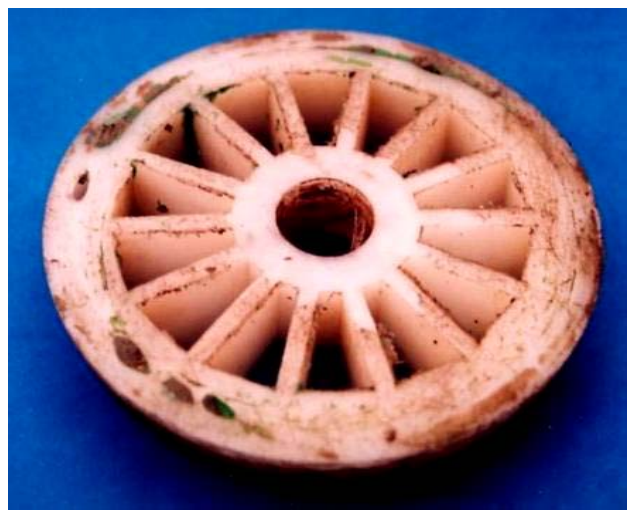

Fig. 5. Follower piston plate and check plate made with plastic disc for piston valve type-I and check valve type-I

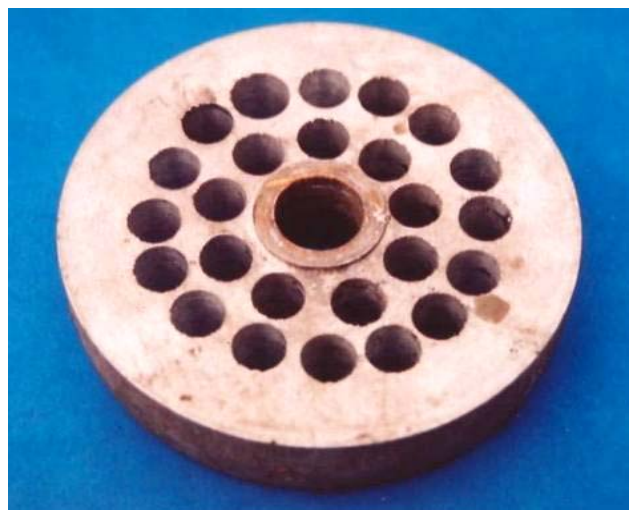

Fig. 2. Piston plate made with perforated cast iron disc of slots size $11 \mathrm{~mm}$ for piston valve type-II

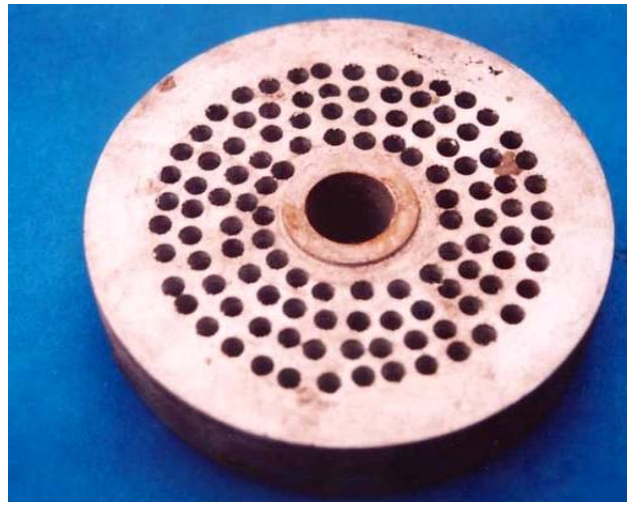

Fig.4. Piston plate made with perforated cast iron disc of slots size $6 \mathrm{~mm}$ for piston valve type-IV

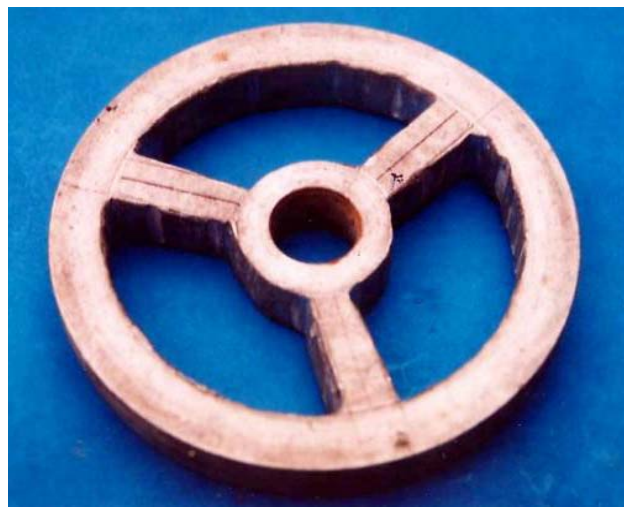

Fig. 6. Follower piston plate made with moulded cast iron disc for piston valve type-II, III and IV 


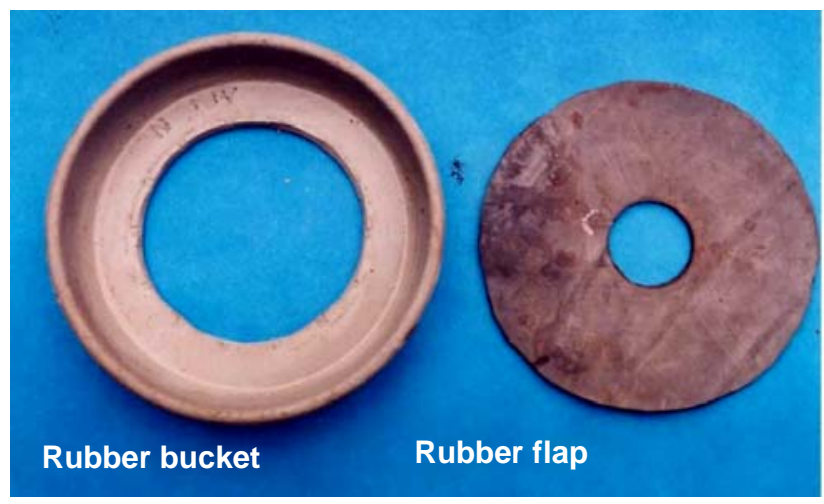

Fig. 7. A photographic view of rubber bucket and rubber flap

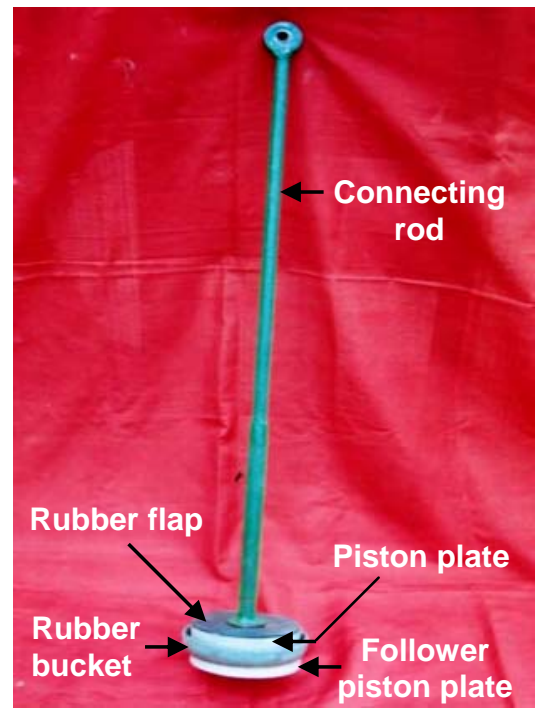

Fig. 8. A photographic view of piston valve assembly with connecting rod

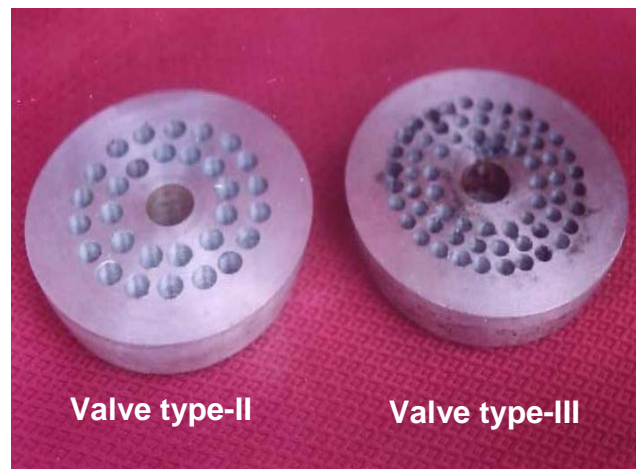

Fig. 9. A photographic view of check plate made with perforated cast iron disc for check valve type-II (slots size $10 \mathrm{~mm}$ ) and III (slots size $7 \mathrm{~mm}$ )

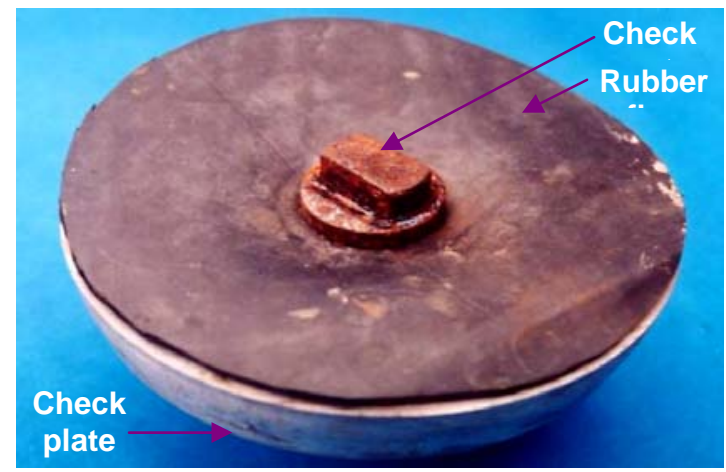

Fig.10. A photographic view of check valve assembly 


\section{Piston valves}

Valve type-I $\left(P V_{i}\right)$

Valve type-II $\left(P V_{\text {ii }}\right)$

Valve type-III $\left(\mathrm{PV}_{\mathrm{iii}}\right) \quad$ :

Valve type-IV $\left(P V_{\text {iv }}\right) \quad$ :

Check valves

Valve type-I $\left(\mathrm{CV}_{\mathrm{i}}\right)$

Valve type-II $\left(\mathrm{CV}_{\mathrm{ii}}\right) \quad$ :

Valve type-III $\left(\mathrm{CV}_{\text {iii }}\right) \quad$ :
Rubber flap mounted plastic disc (Fig.1).

Rubber flap mounted perforated cast iron disc of slots size $11 \mathrm{~mm}$ and about 4 slot openings per square $\mathrm{cm}$ (Fig.2.).

Rubber flap mounted perforated cast iron disc of slots size $8 \mathrm{~mm}$ and about 8 slot openings per 6.45 square $\mathrm{cm}$ (Fig.3).

Rubber flap mounted perforated cast iron disc of slots size $6 \mathrm{~mm}$ and about 16 slot openings per 6.45 square $\mathrm{cm}$ (Fig.4).

\section{Rubber flap mounted plastic disc (Fig.5).}

Rubber flap mounted perforated cast iron disc of slots size $10 \mathrm{~mm}$ and about 5 slot openings per 6.45 square $\mathrm{cm}$ (Fig.9)

Rubber flap mounted perforated cast iron disc of slots size $7 \mathrm{~mm}$ and about 10 slot openings per 6.45 square $\mathrm{cm}$ (Fig.9)

\section{Pump handle}

Pump handle was made using MS rod of $3 \mathrm{~cm}$ diameter having a length of $84 \mathrm{~cm}$ and two $21 \mathrm{~cm}$ length of flat bars. Two flat bars and MS rods were joined together by welding. The top portion of the arm was joined with a connecting rod and last portion of the arm was joined to the fulcrum stand by nuts and bolts. The connecting rod was made of MS rod which was $1.5 \mathrm{~cm}$ diameter having a height of $68 \mathrm{~cm}$, last portion of the lever connected with a foot board which was used to operate the pump with foot. After several test operations lever-arm ratio 4:1was found suitable.

\section{Pedal for lever operation (Foot board)}

The pedal board was made of MS rod. The hanging foot board (pedal) connected with the lever rod was used to move the lever downward with the foot pressure. Operator forced the pedal board downward with his foot which in turn causes the piston rod to move upward with piston plate. The size of this foot board (pedal) was $10 \times 15 \mathrm{~cm}$ and was found comfortable to place foot on it.

\section{Suction pipe}

Five (5) cm PVC pipe was used as a suction pipe and was connected with the pump inlet using an elbow which was found suitable and comfortable.

\section{Principles of pump operation}

The operation of the pump is simple and one adult man can operate the pump easily. During the upward movement of the plunger a negative pressure (vacuum) is created in the cylinder and causes the check valve to open (i.e. the rubber flap moves upward) and water enters into the pumping chamber of the cylinder. When the plunger moves downward the check valve is closed due to positive pressure and a high pressure is created in the pump chamber due to compression of water which in turn opens (the rubber flap moves upward) the plunger valve and water flows across the plunger valve from the suction to the delivery side of the cylinder. Water thus accumulates in the cylinder on the upper side of the plunger valve. When the operator press the pedal with foot to move the lever downward, the plunger moves upward to create negative pressure in the cylinder and accumulated water is then discharged through outlet. Photographic views of the pedal pumps and its operation are presented in Figure 11.

\section{Apparatus required for pump testing}

Graduated tape, stop watch, bucket, measuring cylinder (One litre) and scale were required during the pump test. 
Md. Serazul Islam et al.
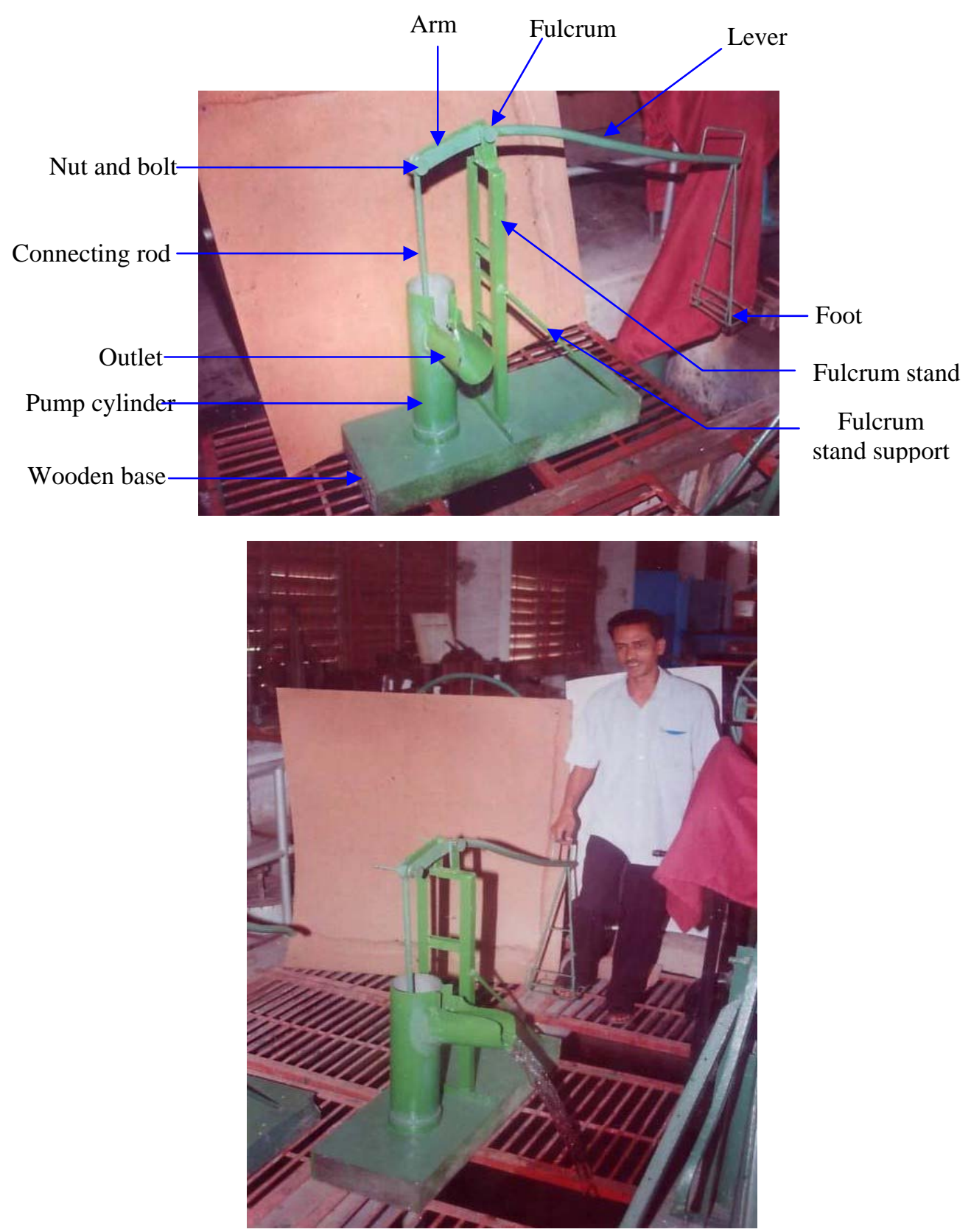

Fig. 11. A photographic view of the pedal pump and its operation

\section{Test procedure}

\section{Measurement of suction head}

The depth of static water level in the laboratory sump was measured directly by a graduated tape from centre of the suction pipe of pedal pump. 


\section{Determination of pump speed}

During the operation of the pump, number of strokes was counted for a known time. The time was recorded by a stopwatch. Dividing the number of strokes by time spent, the pump speed (stroke/min.) was determined.

\section{Determination of pump discharge}

Volumetric method was used to measure pump discharges. A graduated bucket was filled for a known period of time and the time was measured with a stopwatch. The pump discharge in litre per minutes (Ipm) was calculated by dividing the amount of water by the measured time. For each suction head three trial data were taken.

\section{Determination of slip of pump}

Slip of the pump is the difference between the theoretical discharge and actual discharge.

Slip of pump $=$ Theoretical discharge - Actual discharge

$\%$ Slip $=\frac{\text { Slip of pump }}{\text { Theoretical discharge }} \times 100$

\section{Determination of co-efficient of discharge}

Co-efficient of discharge, $C_{d}$ of the pump was determined from the following expression:

$\mathrm{C}_{\mathrm{d}}=\mathrm{V}_{\mathrm{a}} / \mathrm{V}_{\mathrm{t}}$

Where $V_{a}=$ actual volume of water pumped per stroke and $V_{t}=$ theoretical volume

\section{Determination of input power}

The power input of the pump was calculated from the following expression:

$P_{i}=\frac{g W h}{1000 t}$

Where $\mathrm{P}_{\mathrm{i}}=$ input power in $\mathrm{kW}, \mathrm{g}=$ acceleration due to gravity in $\mathrm{m} / \mathrm{sec}^{2}, \mathrm{~W}=$ weight imposed by the operator in $\mathrm{kg}, \mathrm{h}=$ vertical distance (meter) through which the lever move downwards due to foot pressure and $t=$ time (second) required for the downward movement of the lever.

\section{Determination of pump efficiency}

The efficiency of the pump was calculated from the following expression:

$$
E=\frac{P_{0}}{P_{1}} \times 100
$$

Where $\mathrm{E}=$ efficiency in percent, $\mathrm{P}_{\mathrm{o}}=$ output power in $\mathrm{kW}$, and $\mathrm{P}_{\mathrm{i}}=$ input power in $\mathrm{kW}$

\section{Performance testing}

The pump was tested at different suction heads and was operated manually by an average sized man under normal operating conditions. The pump was setup over a platform in a sump of cross section of $6 \mathrm{~m} \times 3.5 \mathrm{~m}$ having the height $2.5 \mathrm{~m}$. The suction head was varied by reducing the water level. The number of strokes that an operator is capable gives in one minute is termed as stroke per minute (spm). For each operation head, water was collected in a large plastic bucket for a few minutes and the collected water was measured by a plastic jug graduated to litre marks. Each test was repeated thrice and in each case, operation period, number of strokes, and water volume were measured. Average discharge per revolution/strokes and discharge per minute (Q) were then calculated. The results of the experimentation have been presented as a graph and each point on a graph represents an average of three discharge rate if all three were within \pm 10 percent of their average. If one value did not fall within the limit, it was rejected and a new average taken for the remaining two discharges. 
Md. Serazul Islam et al.

\section{Pump construction cost}

The costs of pumps were calculated on the basis of present market price and are presented below in Table 1.

\section{Table 1. Item-wise cost of pedal pump}

\begin{tabular}{|c|c|c|}
\hline SI. No. & Materials & Cost (Tk.) \\
\hline 1 & Handle/Lever (MS bar) & 100 \\
\hline 2 & $1.5 \mathrm{~cm}$ dia. connecting rod having $75 \mathrm{~cm}$ length & 40 \\
\hline 3 & PVC cylinder with 5 inch diameter & 80 \\
\hline 4 & Angle bar $(4 \mathrm{~kg})$ for pump support & 160 \\
\hline 5 & Flat bar $(2 \mathrm{~kg})$ for arm & 80 \\
\hline 6 & MS rod ( $3 \mathrm{~kg}$ for pedal pump and $2 \mathrm{~kg}$ for hand pump) & 105 \\
\hline 7 & Cost of iron discs piston valves (10.5 cm dia. \& $2.2 \mathrm{~cm}$ thickness) & 100 \\
\hline 8 & Cost of iron discs check valves (10.2 cm dia. and $1.3 \mathrm{~cm}$ thickness) & 80 \\
\hline 9 & Rubber bucket & 20 \\
\hline 10 & Elbow & 200 \\
\hline 11 & Rubber flaps & 5 \\
\hline 12 & Nuts and bolts & 20 \\
\hline \multirow[t]{2}{*}{13} & Construction cost & 350 \\
\hline & & 1360 \\
\hline
\end{tabular}

\section{Design of Experiment}

Different combination of piston and check valves from four types of piston values $\left(P V_{i}, P V_{i i}, P V_{i i i}\right.$, and PViv) and three types of check valves $\left(\mathrm{CV}_{\mathrm{i}}, \mathrm{CV}_{\mathrm{ii}}\right.$ and $\left.\mathrm{CV}_{\mathrm{iii}}\right)$ were used in this study to find out the best one. The combinations used in this study were $P V_{i}$ and $C V_{i}, P V_{i i}$ and $C V_{i i}, P V_{i i i}$ and $C V_{i i}$, $P V_{\text {iv }}$ and $C V_{i i}, P V_{i i}$ and $C V_{i i i}, P V_{i i i}$ and $C V_{i i i}, P V_{i v}$ and $C V_{i i i}$ respctively.

\section{RESULTS AND DISCUSSION}

The pedal pump were tested in the Hydraulic laboratory of the Department of Irrigation and Water Management, Bangladesh Agricultural University, Mymensingh, Bangladesh under different suction heads using various types of piston and check valves to find out the pump speed, discharge rate, slip of pump, coefficient of discharge, output power, input power, power loss, efficiency and operational suitability. The depth of water level (i.e. suction heads) varied from 0.60 to $2.0 \mathrm{~m}$ depending on laboratory facilities and the stroke length of the pedal pump was within $14-15 \mathrm{~cm}$.

Pump speed, pump discharge rate/capacity, slip of pump, coefficient of discharge, power requirement for pump operation and pump efficiency

Using various sets of valves combination at different suction heads the performance test data of pedal pump are shown in Table 2. Speed of the pump primarily depends on the ability of a pump operator. The highest discharge rates of the pedal pump were $93.27 \mathrm{lpm}$ under the head of $0.6 \mathrm{~m}$ and lowest discharge rates were $57.37 \mathrm{lpm}$ for the head of $2.0 \mathrm{~m}$, respectively, when these pumps were operated with piston valve type-II and check valve type-III. For pedal pump operation the minimum slip occurred with piston valve type-II and check valve type-III. The coefficient of discharges were found higher for pedal pump with piston valve type-II and check valve type-III that of other types of piston and check valves. Higher coefficient of discharge is the indication of the higher pumping efficiency. Lower input power was needed for pedal pump operation. The highest efficiencies were obtained 46.53 percent under a head of $1.65 \mathrm{~m}$, which is shown in Figure 12. Beyond $1.65 \mathrm{~m}$ suction head, the efficiency was found to decrease with the increase of suction head. When the pumps are operated with piston valve type-II and check valve type-III the highest efficiencies were obtained. Pedal operation is comfortable and is not tedious as that experienced in hand operation. 
Design and development of pedal pump for low-lift irrigation

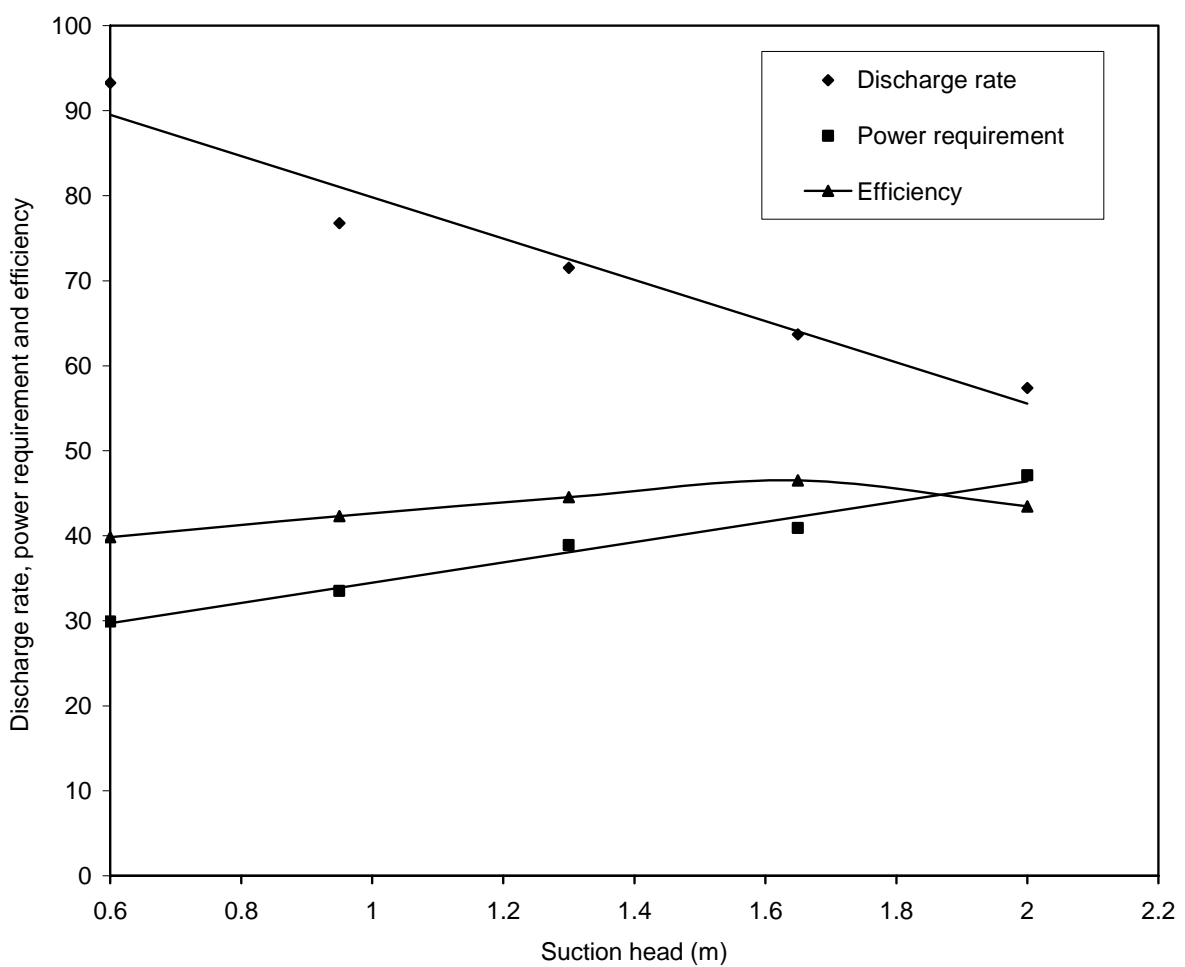

Figure 12. Relationships among discharge rate, power requirement and efficiency with different suction heads

Table 2. Performance test data of pedal pump for various types of valves sets at different suction heads

\begin{tabular}{|c|c|c|c|c|c|c|c|}
\hline Valves Type & $\begin{array}{c}\begin{array}{c}\text { Suction } \\
\text { heads } \\
\text { (m) }\end{array} \\
\end{array}$ & $\begin{array}{l}\text { pump } \\
\text { speed } \\
\text { (spm) } \\
\end{array}$ & $\begin{array}{c}\text { Discharge } \\
\text { rate } \\
\text { (Ips) } \\
\end{array}$ & $\begin{array}{c}\text { Slip of } \\
\text { pump } \\
\text { (Percent) }\end{array}$ & $\begin{array}{c}\text { Coefficient } \\
\text { of } \\
\text { discharge } \\
\end{array}$ & $\begin{array}{c}\text { Power } \\
\text { requirement } \\
\text { (watt) }\end{array}$ & $\begin{array}{c}\text { Pump } \\
\text { efficiency } \\
\text { (Percent) } \\
\end{array}$ \\
\hline Piston valve type I & 0.60 & 52 & 76.79 & 3.73 & 0.963 & 26.3 & 37.27 \\
\hline Check Valve type I & 2.0 & 47 & 47.90 & 26.75 & 0.732 & 41.3 & 41.35 \\
\hline Piston valve type II & 0.60 & 51 & 88.83 & 2.22 & 0.978 & 29.2 & 38.70 \\
\hline Check Valve type II & 2.0 & 49 & 56.96 & 18.86 & 0.811 & 47.9 & 42.33 \\
\hline $\begin{array}{l}\text { Piston valve type III } \\
\text { and }\end{array}$ & 0.60 & 52 & 84.24 & 2.33 & 0.977 & 28.1 & 38.27 \\
\hline Check Valve type II & 2.0 & 48 & 53.83 & 19.08 & 0.809 & 44.5 & 43.13 \\
\hline $\begin{array}{l}\text { Piston valve type IV } \\
\text { and }\end{array}$ & 0.60 & 51 & 80.35 & 2.48 & 0.975 & 27.1 & 37.83 \\
\hline Check Valve type II & 2.0 & 48 & 50.69 & 20.61 & 0.794 & 42.8 & 42.23 \\
\hline $\begin{array}{l}\text { Piston valve type II } \\
\text { and }\end{array}$ & 0.60 & 51 & 93.28 & 1.78 & 0.982 & 29.9 & 39.83 \\
\hline Check Valve type III & 2.0 & 48 & 57.38 & 17.98 & 0.82 & 47.1 & 43.47 \\
\hline $\begin{array}{l}\text { Piston valve type III } \\
\text { and }\end{array}$ & 0.60 & 51 & 88.53 & 1.86 & 0.982 & 28.8 & 39.23 \\
\hline Check Valve type III & 2.0 & 48 & 55.54 & 18.68 & 0.813 & 45.7 & 43.30 \\
\hline $\begin{array}{l}\text { Piston valve type IV } \\
\text { and }\end{array}$ & 0.60 & 51 & 84.24 & 2.15 & 0.979 & 27.6 & 38.87 \\
\hline Check Valve type III & 2.0 & 48 & 53.83 & 19.52 & 0.805 & 45.1 & 42.57 \\
\hline
\end{tabular}




\section{Relationships among discharge rate, power and efficiency with suction heads}

For pedal pump operation inverse relationships were obtained among discharge rate and power requirement with various suction head. The discharge rate was decreases and power requirement was increases with the increases of suction head which shown in Figure 12. At a lower suction head, the pump could be operated with comfort and it produced higher discharge and less power was required to operate the pumps.

\section{DISCUSSION}

The pedal pump was designed and constructed, so that a long time operation is possible with a high efficiency. The constructed pedal pump was found suitable for operation under a suction head up to 2 meters for several hours (more than 2 hours). Islam (2004) worked on twin treadle diaphragm pump and showed suction head beyond $1.7 \mathrm{~m}$ depth the pump was failed to draw water and operator was unable to work more than 1.5 hour continuously. The operation of the pedal pump was found more comfortable and suitability. It was quantified by the maximum operation time during which an average sized man can operate the pump without much physical troubles. When the pump operated using piston valve type-II and check valve type-III were found more suitable than those of compared to other types of valves due to their lower frictional losses and input energy requirement. Pedal pumps are capable of pumping in the range of about 93.27 to $57.38 \mathrm{lpm}$, respectively under the suction head ranging from 0.6 to $2.0 \mathrm{~m}$ with piston valve type-II and check valve type-III whereas Islam (1995) worked on treadle pump and discharge was found $65.4 \mathrm{lpm}$ for a head of $1.12 \mathrm{~m}$. Also, Khan (1998) and Alim (1982) conducted on improved reciprocating hand pump and reciprocating wheel pump and they were found that the discharge were $33.95 \mathrm{Ipm}$ and $50 \mathrm{lpm}$ under a head of $1.14 \mathrm{~m}$ and $2 \mathrm{~m}$, respectively. An average sized man can generate $0.1 \mathrm{hp}$ or $93 \mathrm{w}$ (Anwaruzzaman, 1992). So, the pump could be driven continuously for a long period because input power requirement for the pump operation is smaller than that of the power generated by a man. The highest efficiencies were obtained as 46.53 percent under a head of 1.65 $\mathrm{m}$ but Haq et al. (1994) worked on treadle pump and found 16 percent efficiency for low operating head.

Most of agricultural lands in Bangladesh are fragmented. So, there is a good scope to use the pedal pump to lift water from shallow depth. The pedal pump is capable to tap water from a shallow depth (up to $2 \mathrm{~m}$ ) effectively and is, therefore, expected to be suitable to supply irrigation water in small fragmented land holdings as well as in small irrigation project areas. The pump is portable and can easily be carried to the work place by an average sized adult man. The construction cost is about low (Tk. 1360) due to availability of materials and skills in the local market. Operation and maintenance of the pedal pump is also simple almost to that like UNICEF No. 6 pump. Various parts of the pump are also available at PVC pipe industry and so the pump could be installed at village level with a minimum of cost to pump subsurface water either for irrigation or drinking purposes. Therefore, it is expected that pedal pump due to its lower cost, operation suitability and higher efficiency may gain quick popularity if introduced in rural Bangladesh.

\section{CONCLUSION}

The efficiency of the pedal pump was higher and an operator is capable to work with it for a long time (more than 2 hours) continuously without being tired. The pump is capable to tap water from a shallow depth $(<2 \mathrm{~m})$ effectively and is, therefore, expected to be suitable to supply irrigation water in small fragmented land holdings as well as in small irrigation project areas and construction cost of the pedal pump is also comparatively low and needs about Tk.1360, which is shown in Table 1.

\section{LITERATURE CITED}

Alim, M. A. 1982. Development and fabrication of a wheel pump for low-lift irrigation. A project report submitted to the Department of Irrigation and Water Management, Bangladesh Agricultural University, Mymensingh as a partial fulfillment for the Degree of B.Sc. Agricultural Engineering. pp. 1-39. 
Allison, S. V. 1975. Progress Towards Development of More Appropriate Technology for Land and Water Development in Bangladesh. Proceeding of the Workshop on Appropriate Agricultural Technology, Bangladesh Agricultural Research Council, Dhaka.

Anwaruzzaman, S. M. 1992. Development of manually operated low-lift pump A project report submitted to the Department of Irrigation and Water Management, Bangladesh Agricultural University, Mymensingh as a partial fulfillment for the Degree of B.Sc. Agricultural Engineering. pp. 1-52.

Faruk, M. O. and Pramanik, M. J. 1995. Treadle Pump Irrigation for Technical and Economical Aspects. A project report submitted to the Department of Irrigation and Water Management, Bangladesh Agricultural University, Mymensingh as a partial fulfillment for the Degree of B.Sc. Agricultural Engineering. pp. 1-45.

GOB (Government of Bangladesh). 1986. Bangladesh census of agriculture and livestock 1983-84, Bangladesh Bureau of Statistics, Statistics Division, Ministry of Planning, Dhaka, Bangladesh Vol. 1.

Haq, M. M., Baqui, M. A., Islam, M. T., Islam, M. A. and Haq, K. A. 1994. Feasibility study on different manual pumps in farmer's fields. Bangladesh Rice Research Institute, Gazipur, Bangladesh. AMA. 25 (3): pp. $29-$ 33.

Islam, M. S. 1992. Evaluation of three manual pump mainly: Diaphram pump (BRRI pump), Treadle pump and Rower pump. A report, irrigation and water management Division, Bangladesh Agricultural Research Institute, Gazipur, Dhaka.

Islam, M. S. 2004. Improvement of treadle twin diaphragm pump for low lift irrigation. M.S. Thesis[unpublished], Department of Irrigation and Water Management, Bangladesh Agricultural University, Mymensingh, Bangladesh. pp. 1.

Khan, M. S. H. 1998. Fabriction of an improved reciprocating hand pump for low lift irrigation. A project report submitted to the Department of Irrigation and Water Management, Bangladesh Agricultural University, Mymensingh as a partial fulfillment for the Degree of B.Sc. Agricultural Engineering. pp. 1-42.

Orr, A., Islam, N and Barnes, G. 1991. Treadle pump, manual irrigation for small farmers in Bangladesh. Bangladesh Institute of Development Studies Dhaka, pp. 23-30. 